\title{
Ján Bauko
}

Constantine the Philosopher University in Nitra

\section{Investigation of nicknames in a bilingual environment ${ }^{1}$}

\section{Introduction}

The investigation of the various types of anthroponyms in the Hungarian onomastics has a significant past. The scientific literature dealing with nicknames is ample, but this type of names was not so much investigated in the territories of Slovakia inhabited by Hungarians, only a few essays have been published. Therefore, I considered important the introduction of the system of nicknames in new settlements, to immortalize their traditions and changes of name giving and using.

The goal of my research is above all the thorough investigation of the use of nicknames by Hungarians in Slovakia. I collected the onomastic corpus in four Hungarian settlements in Slovakia (Búč/Búcs, Moča/Dunamocs, Chotín/ Hetény, Iža/Izsa). The state and the verbal looks of nicknames are strongly influenced by the Hungarian-Slovak bilingual environment; therefore, I also investigate in my study the appearing contact phenomena in the onomastic corpus. Primarily I deal with the language use of the adults but I touch upon the denomination habits of the students as well. I analyze both the diachronic and synchronic onomastic corpus. I examine the written nicknames found in written sources, the denomination motives of nicknames used in modern language, the sociolinguistic, dialectological, etymological, onomatophysiological, of word class, morphological and stylistical peculiarities found in the onomastic corpus. I confront the onomastic corpus of the adults and the students and I mention the differences between the nicknames of the two age groups, their denomination and name using habits.

\footnotetext{
${ }^{1}$ The writing of the present paper was supported by VEGA 1/0052/12 „Proper names in context translation and bilingualism".
} 


\section{General information}

The most ancient type of personal name giving is called pagan secular name giving. Many investigators mention as well that heathen names are related to nicknames ${ }^{2}$.

The formation of the two-constituent name giving meant the blending of the heathen and the clerical name forming/making up one specific unit, though the family names arose mainly from nicknames coming from spontaneous name giving and the first names from anthroponyms of clerical origin.

Later on, the necessity of differentiation occurred again. The reasons for formation of new nicknames are to find in the inducing effect of multiplication of identical family and first names, respectively in psychological reasons, in the joking, mocking inclination of the name- -giving community, in the namecreating vitality of the people and in the preservation of traditions. The lingual and the extralingual factors play also a big role in the name selection. The creation and change of proper nouns is dependent primarily on social factors. Blanár $^{3}$ mentions social identification as one of the main functions of proper nouns.

Anthroponyms create a system where the several types of names (family names, first names, monikers and nicknames) are in mutual connection with each other. Nicknames belong to the unofficial group of names, they are mostly used and varied in modern language, in informal discourse situations (in a familiar or social circle) and in smaller separate communities. Nicknames offer the greatest range of names: any linguistic sign or a meaningless sequence of sounds can become a nickname, and nicknames can be chosen freely from the vocabulary of the given language or make up random sequences of sounds for the identification of the person named. Hajdú is of a similar opinion: "any linguistic sign can become a proper noun which is considered one by its creator or user"4. It is in the creation of nicknames that the archaic naming instinct and name creating vitality of humans is manifested. "The natural name creating function of a language is manifested almost exclusively in nickname creation nowadays". This is a productive and dynamic way of name creation: nicknames can be created in any community anywhere in the world. "Nicknames are the most vital type of names in the sense that social and linguistic limita-

${ }^{2}$ Cf. L. Benkö, A magyar tulajdonnevek története, in: A magyar nyelv története, Budapest 1967, p. 382; B. Kálmán, A nevek világa, Debrecen 1989, p. 94.

${ }^{3}$ V. Blanár, Teória vlastného mena. Status, organizácia a fungovanie v spoločenskej komunikácii, Bratislava 1996.

${ }^{4}$ M. Hajdú, Általános és magyar névtan, Budapest 2003, p. 58.

${ }^{5}$ K.J. Soltész, A tulajdonnév funkciója és jelentése, Budapest 1979, p. 56. 
tions are less numerous than in the case of surnames or given names"6. It is up to the creativity and imagination of the creator of the name to decide what kind of name to invent. However, the choice of nicknames is limited by already existing nicknames within the same community. Except in the case of inherited nicknames, an existing nickname is rarely given to a newly named person in order to avoid homonymy. In case homonymous nicknames exist in the same place, they require an additional name element (a diminutive, a given name, or an element referring to age) in order to differentiate and more exactly identify their bearers.

Some experts try to specify the definition of nicknames within other types of anthroponyms: "We call nicknames those name elements which besides official first and family names and diminutives are given by people to each other with certain intentions. For their creation, there must always be a community in which the named and naming individuals know each other personally"'.

\section{Points of research}

By choosing the points of research I took into consideration that in the investigated settlements the inhabitants of Hungarian nationality should form the majority of the local population, have a similar number of inhabitants, belong to one region, be situated close to each other and have a school.

The selected points of research are to find in the Komárno district (okres Komárno). I collected the necessary material in a consistent Hungarian language area in four adjacent villages (Izsa, Hetény, Dunamocs, Búcs). This area did not have a special name in the past, the inhabitants of Komárno call it Vágon túl (region beyond the river Váh), because the mentioned villages are situated beyond the river Váh, east of the town of Komárno. The newer designation of this region is Vág és Garam köz (the region between the rivers Vág and Garam).

The number of people with Hungarian nationality in all four Slovak Hungarian settlements outreach 70\% of the local population (Búč/Búcs 93,6\%, Moča/Dunamocs 92\%, Chotín/Hetény 87,1\%, Iža/Izsa 72,8\%).

Because of historical changes, Slovak Hungarian localities belonged to several countries in the course of the 20th century. In the early 20th century they belonged to Austria-Hungary, then, after World War I, as the result of the 1920 Treaty of Trianon, they became a part of Czechoslovakia. In 1938, under

\footnotetext{
${ }^{6}$ P.B. Gergely, A kalotaszegi magyar ragadványnevek rendszere, Bukarest 1977, p. 65.

${ }^{7}$ M. Hajdú, Magyar tulajdonnevek, Budapest 1994, p. 43.
} 
the Vienna Award, the Hungarian populated areas were reannexed to Hungary. In 1945, they became a part of Czechoslovakia again, whereas in 1993, at the breakup of this country, they went to the Republic of Slovakia. These social changes left their mark on proper nouns as well, especially on names registered in records of births and marriages and on the official use of place names.

\section{Method and sources of the material collection}

In my study, I tried to collect all the written and spoken nicknames. For the investigation of historical nicknames a diachronical examination is needed, therefore I searched for written distinctive names in official records. I tried to review all those available written sources in which there were anthroponyms. In the State District Archives in Komárno (Okresný archív v Komárne), I examined several records, land registers, records about people; in the State Regional Archives in Ivanka pri Nitre (Štátny oblastný archív v Ivanke pri Nitre) I investigated the registers issued between 1722-1895 and in my points of research the state registers having been managed since 1895, respectively in some villages (where there were any) the ecclesiastical registers. Besides these, I also found related nicknames in other sources (village monographs, manuscript, and fiction).

I collected the nicknames used in modern language with a different method for each generation. In the circle of adults I applied the method of active questioning, they answered my questions directly. I recorded on tape a part of my conversation with them. The explanations of the names I also marked phonetically according to the conventional Hungarian phonetic notation, indicating the selfhood of the texts of modern languages. The selection of the informants happened according to many aspects. First, I asked for help my relatives, familiars who live in the villages. Before starting my work in the municipal offices, I asked for the list of names from the population register that helped me a lot during the collection of the nicknames and by the exact identification of the named person. People and families who know each village very well provided the information. From each village I chose individuals from every age group with the same method (10 young - 10 middle-aged -10 old) to provide me with the information I needed, so my research was supported by 120 people. Besides the nicknames of adults, I collected also the nicknames used by students. I did my research in elementary schools with Hungarian as the language of instruction and with the duration of 9 years, which can be found in my points of research (Katona Mihály Elementary School in Búcs, Hungarian Elementary School in Dunamocs, Tarczy Lajos Elementary School in Hetény, 
Döme Károly Elementary School in Izsa). The collection of the nicknames of students was done by a questionnaire. A hundred students in each school filled in the questionnaire, so 400 people took part in the research.

\section{Results}

Nicknames also appear in written sources (registers, land registers, records, etc.). They were fixed because of the necessity for the name to fulfil its identifying function. In the documents in the 18th-20th century examined by me appears as a signal name in these cases: 1 the whole form of the nickname: Válé András (Malac) (Pig), Joannes Varga alias Barát (Friend); 2 the initial letter of the nickname: Cs. Varga Pál (these often referred to the entire family, were inherited as well); 3 maiden family name of the mother or the wife: $\underline{\text { Sárai }}$ Kurucz András; 4 the first or the nickname of the father: Jóska Varga András; 5 marking of the residence: Tóth József Zsitvasori; 6 the profession: takács (weaver) Szabó László; 7 the age: Kovács János Öreg (Senior).

I collected about 1299 nicknames used by adults in the modern language.

By creating the groups according to the name-giving motives, I took as basis the classification of Ördög ${ }^{8}$ and Gergely ${ }^{9}$.

Among the types of nicknames according to name-giving motive the most numerous group is formed by nicknames referred to outer features $(25,17 \%)$. Within this the creation of nicknames is mostly motivated by the shape, stature of an individual (small, tall, fat, thin). The group referred to visible body parts (face, eye, ear, nose, etc.), corporal defects, strangeness and illness is numerous as well and then follows names referred to speech impediment, slip of the tongue and mispronunciation. On the second place are nicknames with unknown and uncertain motive $(21,17 \%)$. In the case of hereditary nicknames, the descendants often do not know the motive of the name giving. In the group of unknown origin, we can also find many nicknames the general meaning of which is apparent, but there is no explanation for the motive of the name giving. We know that the knowledge of the meaning of the name cannot be identified with the motive of the name giving and we could only assume this fact when we rank the names into types. The third most frequent motive is related to the inner features of an individual (14,09\%). The group of names referred to customs, to favourite activities overruns in quantity those ones referred to the dominant feature. Besides the favourite activity, also the favourite

\footnotetext{
${ }^{8}$ F. Ördög, Személynévvizsgálatok Göcsej és Hetés területén, Budapest 1973.

${ }^{9}$ P.B. Gergely, op.cit.
} 
drink or food can often motivate the creation of a name. From the dominant features, the negative human ones prevail. Most names can be found in the subcategories denoting mischief, disobedience, waggery, smartness, lie, stupidity and mental disablement. On the fourth position are the names related to occupation, handicraft and office $(9,85 \%)$. Most of them refer to occupations directly. After these names follow the nicknames with reference to family, first and nicknames (with name-association motive) (9,31\%). The most typical subgroup is formed by the nicknames coming from family names. The young people mainly prefer this name formation method. Names related to events are on the sixth place $(6 \%)$. These are followed by nicknames related to the names of family members and familiars $(5,31 \%)$. The names of male and female ancestors only seldom become nicknames in my points of research. By nicknames coming from the name of the wife, we can observe that the husband is often identified with the maiden family name of his spouse. Among the names referred to oral tradition dominate the ones of own oral tradition. Then the nicknames related to other living conditions (3\%) come where the biggest amount have those related to financial situation, respectively to rearing of farm animals. The names connected to former or current residence $(2,31 \%)$ indicate above all a settlement or part of a boundary. From the name-giving motives the number of nicknames referred to age is the lowest one $(0,69 \%)$. I would like to mention that the reference to age is general in my points of research when the nickname is inherited.

The attitude towards nicknames is influenced by many factors: the namegiving/name-using individual or community, the place of the name's origin, its circumstances, the offending, caustic feature of the name, the name-using setting, the situation (formal or informal), the relationship between the name bearer and name user (friends or enemies), the time elapsed since the name giving, etc. The attitude research shows that most of the name bearers accept their nicknames $(87,14 \%)$. This indicates that the nicknames became an organic part of the community's vocabulary. Following the conversations with the people I can say that the members of the village community identify the name bearer primarily with a nickname and the official family and first name of the person with a nickname is used very rarely in modern language. Many mentioned that the nickname is the right name, the main name in the village and not the people's ordinary, registered name. With the words of one of my informants: "Well, here everybody has a nickname and the nickname is the main name, not their ordinary name". $6,85 \%$ of the name bearers have a positive attitude towards nicknames who like, respectively are proud of their nickname. There are people who find it honourable that they can have the name of notable personalities known from history as a nickname. $6,01 \%$ of the name 
bearers show negative attitude who dislike, respectively hate their nicknames, they find it annoying when somebody calls them like that. The negative, rejecting attitude of the name bearer to the name is visible especially in the case of nicknames with pejorative meaning.

Most of the nicknames have the function of an identifier (66,97\%), but they can be used as a style name as well $(33,03 \%)$.

The colourful world of nicknames makes the investigations of a dialectological aspect possible, though these words live mainly in modern language, in its regional language variant, in the language of the people and therefore the vernacular elements are naturally integrated into the structure of nicknames through the mother dialect. So the vernacular elements can be also found in the system of nicknames. In my investigated points of research people speak the same type of dialect. The local spoken dialect can be ranked into the NorthernDanubian dialect group of the Middle-Transdanubian-Little Alföld (középdunántúli-kisalföldi) dialect region ${ }^{10}$. According to the investigation of dialectological aspect we can say that mostly such phonetic phenomena appear in nicknames that correspond with the dialect. In my points of research, the formal dialect words more often fulfil the function of a nickname than the semantic or original ones. Phraseologisms used in dialects also contain nicknames.

Most of the nicknames are not inherited, they are specific, and therefore the onomastic corpus is dynamically changing with time. 299 out of 1299 nicknames are inherited and represent $23 \%$ of the onomasic corpus. The partial family nicknames (288) overrun in number the family nicknames concerning the entire family (71). From hereditary nicknames 264 are inherited paternally and 35 maternally. The most typical is the inheritance of the father's nickname.

The gender analysis of nicknames demonstrates that men are assigned by nicknames more often than women are: nicknames tend to be a "manly" phenomenon. $86 \%$ of nicknames are related to the male gender and $14 \%$ to the female one. This originates in the relations of village culture, where women were actors in family life rather than in public life - and nicknames are related to the family domain only very weakly. Nicknames are inherited by a male rather than a female line. When inheriting a family nickname, both the wife and the children take the husband's (father's) nickname. Inheriting by the female line happens when a newly wed husband goes to live with his wife and her family.

Males can be given female names as nicknames and vice versa. A man sometimes bears the given name or diminutive of his mother, grandmother, wife, daughter, or female acquaintance (e.g. Gizi Feri, Etel Jancsi, Juliska bácsi

${ }^{10}$ Cf. D. Juhász, A nyelvjárási régiók, in: Magyar dialektológia, Budapest 2001, p. 271-274. 
"uncle Julie", Jutka Balázs), and a woman of her father, grandfather, husband, son, or male acquaintance (e.g. Ádám Gizi, Jeró [from Jeromos] Lujzi, Lukács Bözsi, Márió néni "aunt Mario", Pítyú Ilona).

There is a feminizing tendency that can sometimes be observed in connection with nicknames. A girl who was given a male nickname by the boys in her class in a Hungarian elementary school in Slovakia made up female nicknames for each of the boys (in an act of reciprocal naming), which were then used by the other girls in the class: Géza "(no equivalent)" > Gizike "(diminutive of) Giselle", Karcsika "Charley" > Katika "Katie", Milus-Ilus "Milan" > Iluska "(diminutive of) Helen", Richárd "Richard" > Rebeka "Rebecca", Rózsika "(diminutive of) Rose", Tibor "(no equivalent)" > Tímea "(no equivalent)", Zoli "(no equivalent, diminutive of) Zoltán" > Zita "(no equivalent)". It can be observed that it was the initial letter of the boy's name that played the most important role in the choice of the nickname.

Personal names can also occur in variable name combinations - this is mostly typical of nicknames. In two-part name combinations, the nickname usually precedes the diminutive name and, in effect, replaces the surname: e.g. Buda Gizi "(diminutive of) Giselle Buda", Buszos Kati "Katie of the bus", Hétország Bandi "Bandi of seven countries", Póstás Zsuzsi "(diminutive of) Susan the mailwoman", Rendor Pali "(diminutive of) Paul the policeman". The nickname plus given name combination is used more rarely, which shows that given names are used in their diminutive forms more often in speech (Bokszos Irma "Boxer Irma”, Jézus Lajos "Louis Jesus", Oké Lajos “Louis OK”). In nickname + diminutive combinations the diminutive can precede the nickname (Dzsó Atya "Father Joe", Sári Bíró "Sara the judge"). The nickname can attach to the surname: either precede it (Csusza Varga "sliding Varga", Tóparti Persei "lakeside Persei”), or follow it (Csik Örmester "sergeant Csík", Varga Bótos "shopkeeper Varga"). Nicknames can be augmented with honorary kinship terms (Hajas koma "hairy friend", Márió néni "aunt Mario", Öcsi bácsi "uncle younger brother"). In three-part combinations, the nickname precedes the surname and the given name or diminutive (Idus Lajos Gyula, Márton Nagy András) and it also precedes the diminutive and honorary kinship term (Ferdi Laci bácsi, Szegye Feri bácsi). Nicknames, thus, appear mostly in the first position in combinations and only very rarely in the second.

The name serves for identification; therefore, nicknames are used in combinations of different structures. There are 12 name structures in modern language. The largest part of nicknames is formed by names with a single element $(62,43 \%)$. They themselves identify an individual. This name-using method suggests the ancient single-element name system when an individual had one personal name. Within the type of two-element name associations $(33,56 \%)$ 
the most frequent type structure is nickname + diminutive when the nickname precedes the pet name and fundamentally replaces the family name. The threeelement name combinations appear only rarely (4\%).

From the types of anhtroponyms by the nicknames, we can recognise the common-word origin of the proper name. Therefore, the most typical thing is that common words become proper names. In scientific literature this process is also called onimisation or proprialisation ${ }^{11}$. In many cases, the commonword origin of the nickname can be definitely recognised, but we can often come across the distorted, modified variant of the name. In such cases, the revelation of the name-giving motive can help to detect the character of the common word hidden in the nickname. Even existing proper names (anthroponyms, toponyms, animal names, institution names, brand names, etc.) can become nicknames, so they get into another name type. The change of proper name class is called transonimization. Most of the nicknames in my points of research were formed from nouns $(55,04 \%)$, within them especially from common words $(35,26 \%)$. Nicknames coming from proper names form $19,78 \%$ of the onomastic corpus.

The second most frequent word class serving as the basis for nicknames is the adjective $(24,71 \%)$. From other word classes only a few nicknames were formed.

The most typical method of name formation is the root word, becoming an elemental common word to a proper name and its usage as a nickname $(30,87 \%)$. On the second place are nicknames created by formation $(26,17 \%)$. These are followed by names difficult to rank morphologically $(14,40 \%)$. Nicknames created by change of sound form $6,93 \%$ of the onomastic corpus and those created from foreign common words or proper names form $6,08 \%$. Besides nicknames expressed by word compounding $(5,47 \%)$ and syntagm $(3 \%)$ other name-formation methods play a less important role in name production.

According to the research of the means of expression of nicknames we can say that the creation of a part of expressive nicknames can be explained by the metaphoric usage of the words. Metaphor based on similarity often appears in the onomastic corpus of nicknames as the semantic means for mood creation. From the name-giving motives we can find numerous metaphoric names in the groups of nicknames referred to outer, respectively inner features. Metonymic nicknames are formed through transfer of name based on contact. Many of them can be found among nicknames related to customs, favourite activities and events. The expressiveness of a nickname can be increased by other morphological and phonetic means (e.g. onomatopoetic words, modi-

${ }^{11}$ R. Šrámek, Úvod do obecné onomastiky, Brno 1999, p. 55-56. 
fied, distorted formal variants of proper names, playful name associations, and name-formation methods).

The main differences according to age appear in connection with the use of nicknames by adults and students. By means of the questionnaire method in the elementary schools of my points of research, I collected 868 nicknames in total. The name giving of adults is based essentially on intellectual feature, so monikers came into being for a more exact identification of people with the same name. By students it is mostly the emotional feature that causes the genesis of nicknames. The motives of name giving are similar, but their rate of distribution is different. From the collected onomastic corpus by adults, the largest number constitutes the names related to outer features and those of unknown origin. On the contrary, by students the motive of name giving is mostly known (names of unknown origin are represented less in the onomastic corpus). The most frequent motivation of name giving is related to the family name, the first name or the nickname of the name bearer, the most part of student nicknames were formed with the playful transformation of these names (from those of anthroponymic origin the most frequent are the nicknamed forms of family names). By adults and by students as well as a basis for name giving, the inner feature, an event and the name of family members and familiars serve in similar distribution rate. By students the profession does not appear as a name-giving motive and only slightly the oral tradition, other living conditions, residence, age. Among adults, the distorted formal variants of proper names and common names; while among students lexical common words appear more often. Name combinations of different, diverse structure are typical for the use of nicknames by adults; student nicknames identify within themselves, without any other name element (family name, first name, and nickname). Nicknames of adults generally last longer, they are invariant (they change rarely), the individuals practically have their name given by the village community all their life, this name can be even inherited. The sphere of use of nicknames is larger, they are known and used in a wider ambit, and they mainly function as identifiers. Student nicknames are of short lasting (by getting out from the school community they are not used anymore by the former name bearer), they are variable, they are known and used in a closer community (school, class), they are rarely inherited, and they function as style names. Generally, one name identifies the adult, seldom more adults; at school, usually students name their classmates with 2-3 nicknames. For adults it is typical to use a single nickname, students use more nicknames. The use of nicknames by students is very like to the use of nicknames by adults that is Hungarian dominant, where most of the onomastic corpus is of Hungarian origin. 
Most of the people with nicknames are of older age. The younger generation does not exactly know this onomastic corpus and less and less of them receive a nickname. The once homogeneous village is nowadays getting heterogeneous.

Exogamy, population change and urbanization are not favourable for the creation of nicknames. From the social effects, it was mainly the period after the formation of the Czechoslovak Republic and the era of deportations that influenced the change of the system of anthroponyms of the villages. Nicknames closely connected to the deported people were dropped from everyday use. These names are only alive in the memories of the older generation. The ample balance of nicknames represented the community's consistent power and its name-giving customs. Following the change of population, families that moved in seldom got nicknames from the village community.

The Hungarian speaking community in Slovakia can be seen as bilingual. Slovak Hungarians are able to use the Slovak and the Hungarian language in accordance with the given communication situation. The Hungarian-Slovak bilingual environment influences the use of nicknames by Slovak Hungarians and contact phenomena also appear in the onomastic corpus as the result of language interaction. The ratio of names coming from various languages can/ could refer to the language competence of the community. The individuals receive their nicknames from the members of the community they live in. Therefore, from this name we can somehow deduce the community that created it. In general, people with Hungarian identity receive Hungarian nicknames and only rarely they are identified with Slovak (or other) names. Nicknames can/could refer to the togetherness, to the nationality of the name bearer. The language character of the onomastic corpus of nicknames can/could be formed in consequence of the national distribution of the settlement's population: the more Slovak people inhabit the village, the more is/would be the number of names, contact phenomena coming from Slovak language. In my points of research, people and families of Slovak nationality rarely received a nickname from the members of the Hungarian community in the past. This can be explained by the fact that the Slovak families moved in large numbers to the settlements inhabited by Hungarians after the creation of the Czechoslovak Republic. The majority of people of Slovak nationality living longer in the villages speak (or understand) Hungarian and know the nicknames of the Hungarian population, too. Slovak families that have moved in these areas recently, influence the change of the system of nicknames less because they seldom obtain nicknames from the members of the Hungarian community.

In my points of research, the inhabitants with Hungarian nationality form the majority of the population in the villages that is also shown in the collected 
onomastic corpus: besides the names of Hungarian origin, there are only a few nicknames of Slovak (or other) origin. The Slovak Hungarian investigations of nicknames dealt in the theoretical section show similar results as well. The usage of nicknames by Slovak Hungarians is seen as a mother-tongue dominant (Hungarian dominant).

The ethnic composition of the population of a place has an effect on the language origin of nicknames: it is the dominant language that usually gives the vast majority of nicknames at a given place. The history of the study of nicknames of Hungarians in Slovakia was summarized in Bauko ${ }^{12}$. From the works mentioned there (and from theses supervised by me on the topic) it is clear that in those places where Hungarians constitute the majority of the local population, Hungarian-Slovak bilingualism has a lesser effect on the use of nicknames than in places where Hungarians are the local minority. The greatest part of the corpus is comprised of names of Hungarian origin, while names of Slovak etymology are rare. In the four Hungarian places in Slovakia investigated by me, Búč/Búcs, Moča/Dunamocs, Chotín/Hetény, Iža/Izsa, 2,009 out of the collected 2,131 (or $94.27 \%$ of) nicknames are of Hungarian origin, 72 (or 3.38\%) are of Slovak origin, and 50 (or 2.35\%) originate in another language.

The bilingual environment affects the use of nicknames by Hungarians in Slovakia; also, contact phenomena occur in the name data. Some of the nicknames originate in Slovak loanwords: e.g. Párki "wieners", Ticsinki "salty sticks" (a thin person), Spekacski "sausage" (an overweight person), Csinka "weights" (a strong person). Some nicknames are created through borrowing and association: Burcsák "stum" (from the surname Bircsák), Bandaszka "petrol can" (from the diminutive Bandi of András "Andrew"). Nicknames are sometimes created through translation. A Hungarian surname or its stem can be translated to produce a calqued name: Csontos "bony" > Koszty "bones", Halász "fisher" > Rybár "fisher", Németh "German"> Nyemec "German". The Slovak origin surname of a person can be translated into Hungarian and used as a nickname: e.g. Cibula "onion" > Hagyma "onion", Gula "ball" > Golyó "ball”, Nebehaj “don't run!” > Neszaladj "don't run!”. Code switching also occurs in nickname use - in cases like this, more than one language plays a role in the creation of the name. In the nicknames Bicsis and Bufetos the Slovak stems (bic "whip", bufet "buffet") are augmented with the Hungarian adjective forming derivational suffix $-s$ by analogy to the equivalent Hungarian words ostoros

12 J. Bauko, Ragadványnév-vizsgálatok kétnyelvü környezetben. Négy szlovákiai magyar település ragadványnévrendszere, Nyitra-Budapest 2009; idem, Použivanie antroponým v bilingválnom prostredí, in: Nazwy własne a spoteczeństvo 1, Łask 2010. 
and büfés plus adding a harmonic connecting vowel. One part of two-element nicknames can be of Hungarian origin, the other one Slovak: e.g. Ugrik Zsaba (H. ugrik 'to jump' + Sl. žaba 'frog'), Kis Predszeda (H. kis 'small' + predseda 'president').

The creator of a name can associate to a new name from the phonological form of the surname, given name or diminutive of its bearer: e.g. Anda $>$ Alma “(H.) apple", Banda "(H.) gang”, Honda, Randa "(H.) ugly"; Banai > Banánka "(H.) small banana”; Bircsák > Burcsák (S1. burčák "stum”); Csicsó > Csacsi "(H.) young donkey"; Ďuríček > Bugyícsek (Sl. budiček "wake-up call”); Bálint > Balin, Bálna "(H.) whale”, Bálvány “(H.) idol”; Bandika > Bandaszka (Sl. bandaska "petrol can"); Levente > Leves "(H.) soup", Leveske “(H.) little soup", Naplemente "(H.) sunset”; Sanyika > Szanitka (Sl. sanitka "ambulance"). The official name Marcsa Márk was the basis for the hapaxlike name Harcsapárki (H. harcsa "catfish" + Sl. párky "wieners") created by association.

A nickname is created by semantic association if the descriptive name (usually a homonym of their surname) of a person is associated with a word (or words) of the same semantic class and becomes a nickname: e.g. Zsemle "bread roll" > Hamburger "hamburger", Hotdog "hot dog", Kenyér "bread", Kifli "croissant", Morzsa "bread crumbs". A surname can also be replaced by a synonymous or antonymous word: e.g. Baráth "friend" > Haver "buddy", Pajtás "buddy", Kosár "basket" > Szatyor "shopping bag"; Farkas "wolf" > Bárány "sheep", Nagy "big"> Apró "small”, Picur "tiny”, Pénzes "wealthy" > Nincstelen "destitute", Szegény "poor". A Hungarian surname of common noun origin can also create an association to a Slovak word of the same semantic class and become a nickname: e.g. Bogár "beetle" > Pavúk (Sl. pavúk "spider"). Here we have a hyperonymic relationship: hyperonym (beetle): hyponym (spider).

The speech community of Hungarians in Slovakia is a bilingual speech community. In bilingual communities, people can choose names from a wider range. Choosing a variant of a personal name from one language or the other can depend on several factors: the communicative domain, the communication partners, the social or linguistic context etc.

Investigation of the nickname vocabulary is one of the current tasks of the Slovak Hungarian linguistics. In the future, I would like to continue with my research and expand it on other regions and areas inhabited by Hungarians in Slovakia. The extensive database will give the opportunity for comparative investigations and larger generalizations. 


\section{Ján Bauko}

\section{Investigation of nicknames in a bilingual environment}

The author examines the use of nicknames by the Hungarians in Slovakia. Since the state and the verbal representation of nicknames are strongly influenced by the Hungarian-Slovak bilingual environment, the appearing contact phenomena in the anthroponymic corpus are also investigated in this study. In addition, the paper deals with written nicknames found in written sources, the denomination motives of nicknames used in modern language, sociolinguistic, dialectological, etymological, morphological, and stylistic peculiarities found in the onomastic corpus. The usage of nicknames of adults and students is confronted and discussed with reference to an empirical and comparative study.

KeY wORDs: onomastics, anthroponyms, nicknames, use of nicknames by Hungarians in Slovakia, bilingual environment.

dr Ján Bauko, Instytut Językoznawstwa Węgierskiego, Teorii Literatury i Metodologii Badań Literackich, Wydział Studiów Środkowoeuropejskich Uniwersytetu Konstantyna Filozofa w Nitrze (Słowacja), członek komisji onomastycznej Słowackiej Akademii Nauk, członek stowarzyszony Węgierskiej Akademii Nauk; zainteresowania badawcze: zagadnienia onomastyczne i socjolingwistyczne. 